Article

\title{
Durability of Structural Lightweight Concrete Containing Different Types of Natural or Artificial Lightweight Aggregates
}

\author{
Efstratios Badogiannis ${ }^{1, *(\mathbb{D})}$, Maria Stratoura ${ }^{1,2} \mathbb{D}$, Konstantinos Aspiotis ${ }^{3} \mathbb{D}$ and Alexandros Chatzopoulos 4 \\ 1 School of Civil Engineering, National Technical University of Athens, 15773 Athens, Greece; \\ mariastrat@gmail.com \\ 2 Department of Environmental Engineering, University of Patras, 30100 Agrinio, Greece \\ 3 School of Chemical Engineering, National Technical University of Athens, 15773 Athens, Greece; \\ aspiotis@mail.ntua.gr \\ 4 Department of Civil Engineering, Democritus University of Thrace, 67100 Xanthi, Greece; \\ achatzop@civil.duth.gr \\ * Correspondence: badstrat@central.ntua.gr; Tel.: +30-2107-7212-66
}

Citation: Badogiannis, E.; Stratoura, M.; Aspiotis, K.; Chatzopoulos, A. Durability of Structural Lightweight Concrete Containing Different Types of Natural or Artificial Lightweight Aggregates. Corros. Mater. Degrad. 2021, 2, 554-567. https://doi.org/ $10.3390 / \mathrm{cmd} 2040029$

Academic Editor: Jose M. Bastidas

Received: 4 August 2021

Accepted: 22 September 2021

Published: 28 September 2021

Publisher's Note: MDPI stays neutral with regard to jurisdictional claims in published maps and institutional affiliations.

Copyright: () 2021 by the authors. Licensee MDPI, Basel, Switzerland. This article is an open access article distributed under the terms and conditions of the Creative Commons Attribution (CC BY) license (https:// creativecommons.org/licenses/by/ $4.0 /)$.

\begin{abstract}
Different structural lightweight concrete mixtures of specific density and strength classes were produced by using various lightweight aggregates (LWAs) such as pumice, perlite, and rice husk ash. Their properties were evaluated in fresh and hardened states with regards to compressive strength and durability parameters such as water absorption (open porosity and capillary absorption), chloride's penetration resistance, and carbonation depth. According to the results, most LWA concrete mixtures performed satisfactorily in terms of the designed strength and density and they could be used as structural LWA concrete mixtures. As far as the durability of LWA concrete was concerned, open porosity and resistance to the carbonation of LWA concrete were burdened with the porous nature of LWAs, while sorptivity in some mixtures and especially chlorides' penetration resistance in all mixtures were reported to be significantly improved. The overall strength and durability performance of the designed LWA concrete mixtures could mitigate the concerns stemming from its vulnerability to extreme exposure conditions.
\end{abstract}

Keywords: lightweight concrete; pumice; perlite; rice husk ash; strength; durability

\section{Introduction}

Concrete is one of the most important levers of development for contemporary society and often its consumption level constitutes an index of development rate. Its main usage in infrastructure and residential buildings presupposes improved flexural performance that imposes steel reinforcement [1]. The durability of reinforced concrete (RC) is assured by a concrete cover, as the latter is an exceptionally durable material that protects steel from corrosion. However, all materials degrade over time-especially steel, which is extremely susceptible to corrosion [2].

Steel corrosion is an electrochemical process that involves water and oxygen and it is influenced by aggressive environmental agents such as $\mathrm{CO}_{2}$ and chlorides $\left(\mathrm{Cl}^{-}\right)$[3] $\mathrm{Cl}^{-}$found in seawater and anti-frost salts used in highways are especially of concern in $\mathrm{RC}$ structures as they are extremely aggressive agents that promote non-uniform corrosion [4]. Chlorides are induced in concrete through the mechanisms of capillary absorption, hydrostatic pressure, and diffusion. The latter is considered as the main mechanism of chlorides' ingress and refers to the movement of chlorides' solutions that equalizes their concentration differences [5].

When concrete's steel reinforcement rusts, the fragility of the RC structures increases and their durability degrades. However, durability, together with the rational use of raw or recycled materials, are considered key parameters for sustainable concrete structures [6]. Durable and sustainable design is emphasized in the newly imposed EN standards and 
structural building codes [7] since environmental, social, and economic performance are equally considered with the technical and functional requirements of the structures [8]. At the same time, the European community steadily promotes industrial ecology and sustainability in the raw materials used for the production of concrete [9]. Therefore, the technological development of unconventional concrete that exploits alternative raw or recycled aggregates such as lightweight concrete (LWC) is considered valuable. Nevertheless, at the intersection of these two essential parameters of concrete sustainability, such as durability and the rational use of raw or recycled materials, the research community ought to continuously evaluate alternative materials for the production of concrete and to examine whether their usage affects the durability of concrete.

In the recent literature, different types of LWAs have been examined for the production of LWC [10]. Pumice is one of the most widely used natural lightweight aggregates [11,12]. In addition to its use as an LWC aggregate and due to its mineralogy, ground pumice is also used as a cement replacement material, since it exhibits pozzolanic reactivity. Hossain examined the effect of pumice addition in mortars at a cement replacement percentage of $10-40 \%$ and reported a strength increase of up to $20 \%$ [13]. Research into the mechanical and durability characteristics of concrete with pumice-blended cement has also been the subject of other publications, where improvement in the both strength and durability of LWC is also reported [14,15]. Additional research into the durability of LWC containing pumice as aggregates will provide constructive enrichment on the strength and durability characteristics of pumice concrete [16].

Perlite is another natural lightweight aggregate that is widely used in LWC, mainly in its expanded form. Perlite is expanded when it is rapidly heated to a temperature that exceeds its softening point $\left(900-1200^{\circ} \mathrm{C}\right)$ [17]. Expanded perlite can be used in concrete by replacing part of cement or aggregates, as it provides good thermal and sound insulation, satisfactory fire resistance, and low density [18]. However, its porous nature affects the workability of concrete and as more water is necessary for the soaking of the perlite aggregates, the strength of LWC is counted to be decreased [19]. Research on sealing the open pore system of expanded perlite mainly by applying hydrophobic coatings has already been reported in the literature $[20,21]$ and further investigation into the subject will be productive.

Moreover, there is significant research work on using wastes as substitution material of fine aggregate [22,23] in concrete, in an attempt to further promote sustainability. In this context, run of mine (Pe) perlite, a raw perlite stream of $0-2 \mathrm{~mm}$ or $0-4 \mathrm{~mm}$ grade which it rejected as a waste from the perlite expansion process, could substitute fine aggregates in concrete. Until today, only ultra-fine run of mine perlite has been promoted [24] or studied [25] as effective in supplementing the cementitious material of concrete. Some preliminary work on the exploitation of finer than $4 \mathrm{~mm}$ perlite as fine aggregates of LWC returned satisfactory results in terms of strength and durability [26]; however, more research will be constructive. Furthermore, rice husk ash (R), an agro-industrial residue derived from the controlled burning of rice husk could also be used instead of fine aggregates. It has very low bulk density and it is rich in silica, where in many cases-depending on its nature and burning/cooling condition-the total silica of R exceeds $90 \%$ [27]. Many researchers have already investigated the pozzolanic action of $R$ in concrete and they have obtained very satisfying results [28]. However, the deposition of $R$ waste is enormous, and its further use as an aggregate could relieve the environmental pressure. Research in this direction and using $\mathrm{R}$ as a fine aggregate material can be found in the literature $[26,28]$.

This study investigated the potential use of alternative raw materials as aggregates in the production of structural lightweight concrete of specified strength and density classes, such as minimum strength class LC28/30 and maximum density class D1.6, respectively. Their usage is expected to contribute to both the rational usage of raw materials and the exploitation of industrial wastes- thus endorsing sustainability. Thus, non-conventional aggregates such as pumice $(\mathrm{Pu})$, perlite $(\mathrm{Pe})$, rice husk ash $(\mathrm{R})$, and waterproof expanded perlite $(\mathrm{ePe})$ were selected and combined to produce eight different concrete mixtures. The 
fresh properties, mechanical characteristics, and durability parameters of the lightweight concrete mixtures were studied. The results demonstrate whether the designed concrete mixtures satisfy the specified density and strength classes. In addition, they are expected to illustrate the role of LWAs in the strength development and durability of concrete.

\section{Materials and Methods}

Lightweight aggregate concrete (LWC) was produced by using four different LWAs, pumice $(\mathrm{Pu})$, perlite $(\mathrm{Pe})$, expanded perlite $(\mathrm{ePe})$, and rice husk ash (R). Tables 1 and 2 list their chemical composition and their physical properties (apparent density- $\rho_{\mathrm{a}}$ and water absorption-A), respectively. Typical Portland cement CEM I 42,5R (OPC) was used in the concrete mixtures and its chemical composition is also presented in Table 1.

Table 1. Chemical analysis ( $\% w / w)$ of used materials.

\begin{tabular}{ccccccccccccc}
\hline & $\mathbf{S i O}_{2}$ & $\mathrm{Al}_{2} \mathbf{O}_{3}$ & $\mathrm{Fe}_{2} \mathbf{O}_{3}$ & $\mathbf{C a O}$ & $\mathbf{M g O}$ & $\mathbf{S O}_{3}$ & $\mathbf{K}_{\mathbf{2}} \mathbf{O}$ & $\mathbf{N a}_{\mathbf{2}} \mathbf{O}$ & $\mathbf{T i O}_{2}$ & $\mathbf{P}_{2} \mathbf{O}_{5}$ & $\mathbf{Z n O}$ & L.O.I. \\
\hline $\mathrm{OPC}$ & 20.06 & 4.91 & 3.51 & 62.19 & 3.11 & 2.71 & 0.50 & 0.20 & - & - & - & 2.81 \\
$\mathrm{Pu}$ & 68.22 & 11.83 & 1.15 & 4.09 & 0.44 & - & 4.00 & 2.76 & 0.12 & 0.03 & - & 7.37 \\
$\mathrm{Pe}$ & 73.82 & 12.97 & 1.00 & 1.40 & 0.25 & - & 3.49 & 4.49 & - & - & - & 2.59 \\
$\mathrm{R}$ & 90.59 & 0.08 & 0.45 & 1.22 & 0.48 & - & 0.84 & 0.66 & - & - & 0.02 & 5.66 \\
\hline
\end{tabular}

Table 2. Physical properties of aggregates.

\begin{tabular}{ccccccccccc}
\hline & $\mathbf{P u}$ & $\mathbf{P u}$ & $\mathbf{P u}$ & $\mathbf{P e}$ & $\mathbf{P e}$ & $\mathbf{e P e}$ & $\mathbf{R}$ & $\mathbf{C a}$ & $\mathbf{C a}$ & $\mathbf{C a}$ \\
& $(\mathbf{0}-\mathbf{4})$ & $(\mathbf{2}-\mathbf{1 0})$ & $\mathbf{( 0 - 1 6 )}$ & $\mathbf{( 0 - 2 )}$ & $\mathbf{( 0 - 4 )}$ & $\mathbf{( 0 - 2 )}$ & $\mathbf{( 0 - 2 )}$ & $\mathbf{( 0 - 4 )}$ & $\mathbf{( 4 - 8 )}$ & $\mathbf{( 8 - 1 6 )}$ \\
\hline$\rho_{\mathrm{a}}\left(\mathrm{t} / \mathrm{m}^{3}\right)$ & 1.61 & 1.39 & 1.13 & 2.20 & 2.15 & 0.96 & 1.79 & 2.67 & 2.67 & 2.61 \\
\hline $\mathrm{A}(\%)$ & 19.3 & 17.0 & 17.0 & 4.0 & 3.4 & 21.0 & 13.7 & 2.1 & 0.90 & 0.90 \\
\hline
\end{tabular}

A special treatment was performed only on ePe and R aggregates. More specifically, expanded perlite was subjected to heat treatment at $400{ }^{\circ} \mathrm{C}$ for $4 \mathrm{~h}$ in order to expel interlayer-adsorbed water and then immersed for $24 \mathrm{~h}$ in a waterproofing media. Rice husk was also thermally treated at $700{ }^{\circ} \mathrm{C}$ for $2 \mathrm{~h}$, to burn out the remaining carbon content.

A mix design blended the different types and grades of LWAs. Figure 1 presents the grain size curves of all the aggregates used in this study. Pumice $(\mathrm{Pu})$, of nominal grading $0-4,0-8$, and $0-16 \mathrm{~mm}$; perlite (Pe) of $0-2$ and $0-4 \mathrm{~mm}$ nominal grading; and rice husk ash (R) 0-2 mm nominal grading; as well as three locally available crushed calcareous limestone aggregates $(\mathrm{Ca})$ of nominal grading $0-4,4-8$, and $8-16 \mathrm{~mm}$, were used. The mix design aimed to produce compact concrete mixtures of similar density (D1.6) and strength class (LC28/30), according to EN206-1 [29].

Table 3 summarizes the syntheses of the seven different LWA concrete mixtures that were compared to a reference mixture (REF) which contained only calcareous normal weight aggregates (NWAs). The water-to-cement ratio $(\mathrm{w} / \mathrm{c})$ for all mixtures was kept constant $(0.40)$, considering the absorption capacity of the aggregates (Table 2). Appropriate superplasticizer (SP) dosage ( $\% w / w$ of cement) was used to regulate the workability of LWC mixtures. The theoretical density of LWC mixtures was calculated as the summary of ingredients and it was considered in the mix design procedure.

In order to study the properties and the durability characteristics of LWA concrete, a batch volume of $15 \mathrm{~L}$ was produced for each concrete mixture. Seven cubic specimens of $100 \times 100 \times 100 \mathrm{~mm}^{3}$, two cylindrical specimens of $200 \mathrm{~mm}$ height and $100 \mathrm{~mm}$ diameter, and 12 cubic specimens of $70 \times 70 \times 70 \mathrm{~mm}^{3}$ were cast for each mixture. After 1 day of moist curing, the specimens were water-cured at $23 \pm 1{ }^{\circ} \mathrm{C}$ for 28 days. Compressive strength was measured at 2, 7, and 28 days. The mean value of two (at 2, 7 days) or three (at 28 days) cubic specimens was calculated. 


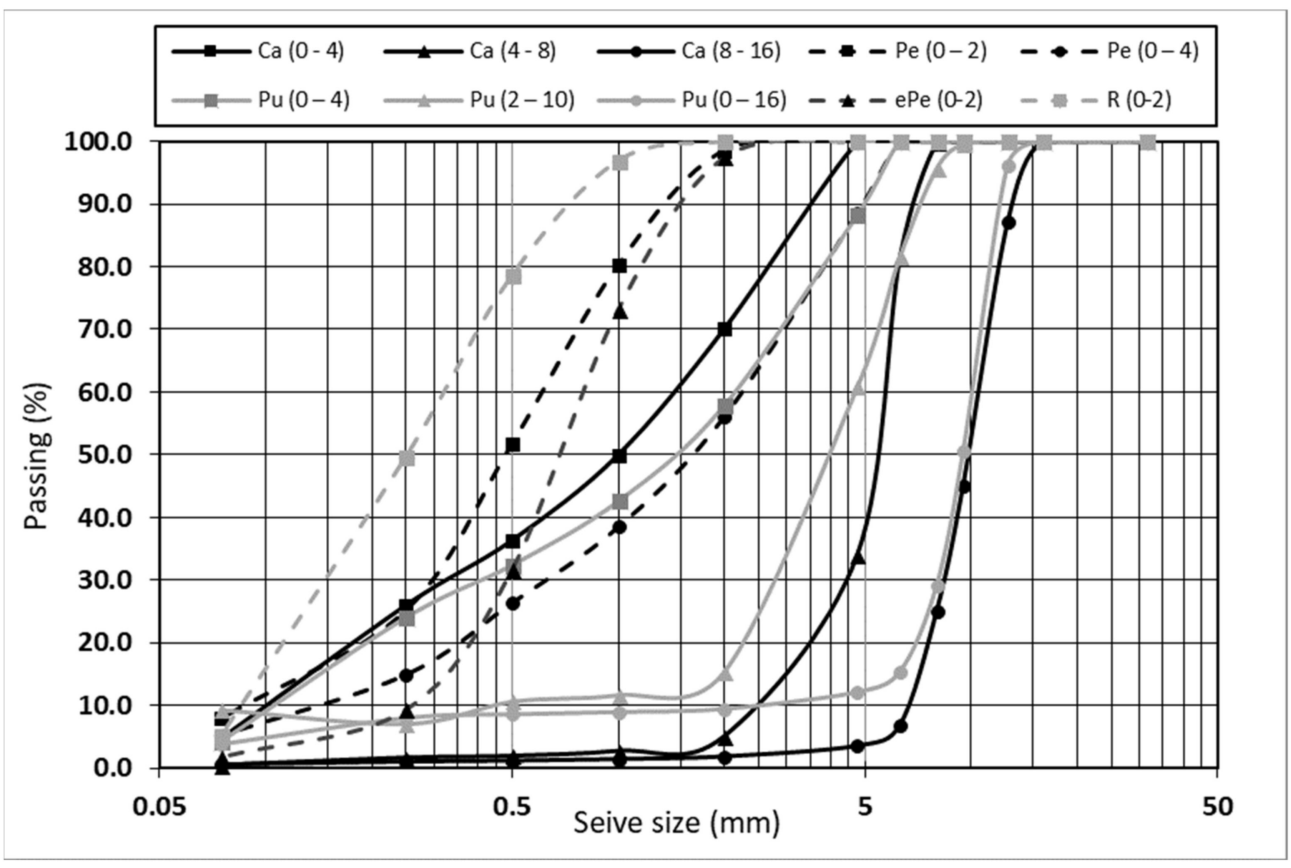

Figure 1. Grading curves of all aggregates used in the different concrete mixtures.

Table 3. Concrete mixtures proportions $\left(\mathrm{kg} / \mathrm{m}^{3}\right)$.

\begin{tabular}{ccccccccc}
\hline \multirow{2}{*}{ Materials } & \multicolumn{8}{c}{ Mixture } \\
\cline { 2 - 8 } & REF & PeCaPu & ePeCaPu & PePu & RCaPu & Pu & ePePu & RPu \\
\hline Cement & 400 & 400 & 400 & 400 & 400 & 400 & 400 & 400 \\
Ca (0-4) & 948 & - & - & & - & - & - & - \\
Ca (4-8) & 569 & 57 & - & - & 89 & - & - & - \\
Ca (8-16) & 379 & - & 107 & - & - & - & - & - \\
Pe (0-2) & - & 114 & - & 158 & - & - & - & - \\
Pe (0-4) & - & 512 & 479 & 243 & - & - & 215 & - \\
Pu (0-4) & - & - & - & 190 & 412 & 537 & 168 & 287 \\
Pu (0-16) & - & 455 & 320 & 464 & 446 & 381 & 410 & 421 \\
Pu (2-10) & - & - & - & - & - & 59 & - & 105 \\
ePe (0-2) & & - & 160 & - & - & - & 140 & - \\
R (0-2) & - & - & - & - & 167 & - & - & 144 \\
Effective water & 160 & 160 & 160 & 160 & 160 & 160 & 160 & 160 \\
SP & 1.4 & 2.6 & 2.7 & 1.5 & 10.2 & 2.7 & 2.8 & 5.6 \\
\hline SUM & 2457 & 1701 & 1629 & 1617 & 1684 & 1540 & 1496 & 1523 \\
\hline
\end{tabular}

The durability of LCW mixtures was evaluated based on the water absorption (open and capillary porosity), chloride's penetration resistance, and the carbonation depth on specimens cured for at least 28 days. The open porosity $(p)$ was evaluated according to ASTM C 642 [30], after 28 and 90 days of curing. The sorptivity test was applied to a concrete cylinder disc of $100 \mathrm{~mm}$ diameter and $50 \mathrm{~mm}$ height, at the age of 28 days and the sorptivity, $\left(\mathrm{S}, \mathrm{mm} / \mathrm{min}^{0.5}\right)$ was calculated in compliance with the RILEM Technical Recommendation [31].

The chloride migration was estimated according to NT Build 492 [32]. The (apparent) chloride penetration coefficient, $D_{\text {nssm }}\left(\times 10^{-12} \mathrm{~m}^{2} / \mathrm{s}\right)$ was calculated on a $50 \mathrm{~mm}$-thick segment extracted from the middle zone of two different cylindrical specimens. The specimens were maintained for $24 \mathrm{~h}$ under a potential difference between a cathode solution of $10 \% w / w$ sodium chloride $(\mathrm{NaCl})$ and an anode solution of $0.3 \mathrm{~N}$ sodium hydroxide $(\mathrm{NaOH})$. Afterwards, each specimen was split and the determination of the chloride migration depth was performed by a colorimetric method. According to the 
method the two pieces were sprayed with a $0.1 \mathrm{M}$ silver nitrate $\left(\mathrm{AgNO}_{3}\right)$ solution and the displayed chloride depth profile was measured. The calculation of coefficient $\mathrm{D}_{\text {nssm }}$ was performed at two concrete ages: 28 and 90 days.

The carbonation depth was measured using the cubic specimens of $70 \mathrm{~mm}$ edge. Specimens were water cured for at least 90 days and then placed in a laboratory environment until testing. After seven days, a set of specimens were placed into the accelerating carbonation chamber $\left(\mathrm{T}=20^{\circ} \mathrm{C}\right.$, relative humidity $\left.=55 \%, \mathrm{CO}_{2}=1 \% v / v\right)$ where they remained until the measuring date, i.e., 60 and 120 days.

Finally, photos were captured using scanning electron microscopy (SEM) of the concrete samples after 90 days of curing and the paste as well as the transition zone between cement paste and coarse aggregates were studied. The used SEM was a Jeol JSM-5600 instrument, operating at $20 \mathrm{keV}$ and $0.5 \mathrm{nA}$.

\section{Results and Discussion}

The properties of fresh and hardened concrete for all concrete mixes are presented in Table 4. The density values of the lightweight mixtures in fresh condition ranged from $1477 \mathrm{~kg} / \mathrm{m}^{3}$ to $1661 \mathrm{~kg} / \mathrm{m}^{3}$, and while in a hardened state, ranged between 1250 and $1504 \mathrm{~kg} / \mathrm{m}^{3}$. According to ACI 211.2-98 [33], all the mixtures could be considered lightweight concretes. Moreover, the density values of the mixtures satisfy the initial goal of the mix design regarding the classification of the LWC mixtures in density classes below D1.6, as specified by EN206-1 [29].

Table 4. Test results for all concrete mixtures in fresh and hardened states.

\begin{tabular}{|c|c|c|c|c|c|c|c|}
\hline \multirow{2}{*}{ Mixture } & \multirow{2}{*}{ Slump (mm) } & \multirow{2}{*}{ Air Content (\%) } & \multirow{2}{*}{$\begin{array}{c}\text { Density (Fresh) } \\
\left(\mathrm{kg} / \mathrm{m}^{3}\right)\end{array}$} & \multirow{2}{*}{$\begin{array}{l}\text { Density } \\
\text { (Dry) } \\
\left(\mathrm{kg} / \mathrm{m}^{3}\right)\end{array}$} & \multicolumn{3}{|c|}{ Compressive Strength (MPa) } \\
\hline & & & & & $2 \mathrm{~d}$ & $7 \mathrm{~d}$ & $28 \mathrm{~d}$ \\
\hline REF & 100 & 1.5 & 2427 & 2295 & 51.61 & 60.30 & $68.8 \pm 2.6$ \\
\hline $\mathrm{PeCaPu}$ & 23 & 4.8 & 1661 & 1504 & 26.65 & 31.42 & $35.0 \pm 1.5$ \\
\hline $\mathrm{ePeCaPu}$ & 10 & 4.8 & 1583 & 1426 & 24.09 & 29.25 & $29.5 \pm 0.4$ \\
\hline $\mathrm{PePu}$ & 40 & 5.1 & 1577 & 1408 & 22.81 & 26.23 & $29.8 \pm 0.3$ \\
\hline $\mathrm{RCaPu}$ & 10 & 3.0 & 1570 & 1395 & 16.17 & 20.81 & $28.1 \pm 1.9$ \\
\hline $\mathrm{Pu}$ & 60 & 6.3 & 1506 & 1279 & 19.61 & 24.15 & $26.4 \pm 0.6$ \\
\hline $\mathrm{RPu}$ & 20 & 5.0 & 1495 & 1250 & 18.08 & 21.59 & $28.4 \pm 1.8$ \\
\hline $\mathrm{ePePu}$ & 10 & 6.9 & 1477 & 1285 & 19.28 & 25.05 & $26.7 \pm 0.6$ \\
\hline
\end{tabular}

The workability of the concrete mixtures was certainly affected by the porous nature of the used lightweight aggregates. The reported slump values of lightweight mixtures were constantly lower than the slump of the reference mixture, despite the fact that more than double the amount of superplasticizer was initially consumed (Table 3) in order to achieve the basic workability of the two first slump classes-S1-S2 - of the EN206-1 [29]. The PePu and $\mathrm{Pu}$ mixtures seemed to respond well to the superplasticizer addition since they consumed a relatively low dosage in order to approach the slump of the reference mixture. On the other hand, mixtures with R exhibited very poor rheology, despite the fact that they consumed a higher dosage of SP. In any case, the workability of the studied lightweight concrete mixtures needs further optimization and it should be undertaken in the next experimental program of the current research. At the same time, the air content of the mixtures was measured to be increased, due to both the porous nature of the LWC mixtures and the additional SP dosage which certainly affected the air content values [34].

With regard to the compressive strength, the results for conventional concrete (REF) and light-weight concrete mixtures after 2, 7, and 28 days of curing are illustrated in Table 4. Undoubtedly, the addition of LWAs instead of normal weight aggregates not only reduced the weight of concrete but also its compressive strength. The compressive strength followed a clear reduction trend in accordance with the decreasing trend of the density of the mixtures. The PeCaPu and PePu mixtures exhibited strength values above or near $30 \mathrm{MPa}$, respectively. 
In sequence, the average strength values at 28 days and standard deviation were used for the calculation of the characteristic strength $\left(f_{c}\right)$ for all mixtures, in order to classify concrete mixtures to the specified strength classes according to EN206-1 [29]. Figure 2 compares the characteristic strength and (dry) density of concrete mixtures in order to examine the strength equivalence between the LWC mixtures in terms of density. Thus, the mixtures are presented in descending order according to their density values. As shown, the $\mathrm{PeCaPu}$ mixture and $\mathrm{ePeCaPu}$ and $\mathrm{PePu}$ mixtures (marginally) satisfy the primary experimental aim of this study as far as both the minimum strength class (LC28/30) and maximum density class (D1.6) are concerned. The other mixtures, although they were not classified in this strength class, could still be recommended as structural LWC mixtures (strength class LC20/25). Additionally, by comparing mixtures that are categorized in the D1.6 density class $(\mathrm{PeCaPu}, \mathrm{ePeCaPu}$, and $\mathrm{PePu})$, the $\mathrm{PePu}$ mixture managed to approach the lower limit of the strength class (30 MPa), having density near to the lower limit of the density class $\left(1408 \mathrm{~kg} / \mathrm{m}^{3}\right)$, respectively. The PeCaPu mixture was classified in the strength class LC28/30 and in the density class D1.6. It seems that the other mixtures, although categorized in lower strength (LC20/25) and density (D1.4) classes, could also fulfill the experimental goals of the subsequent classes after further optimization.

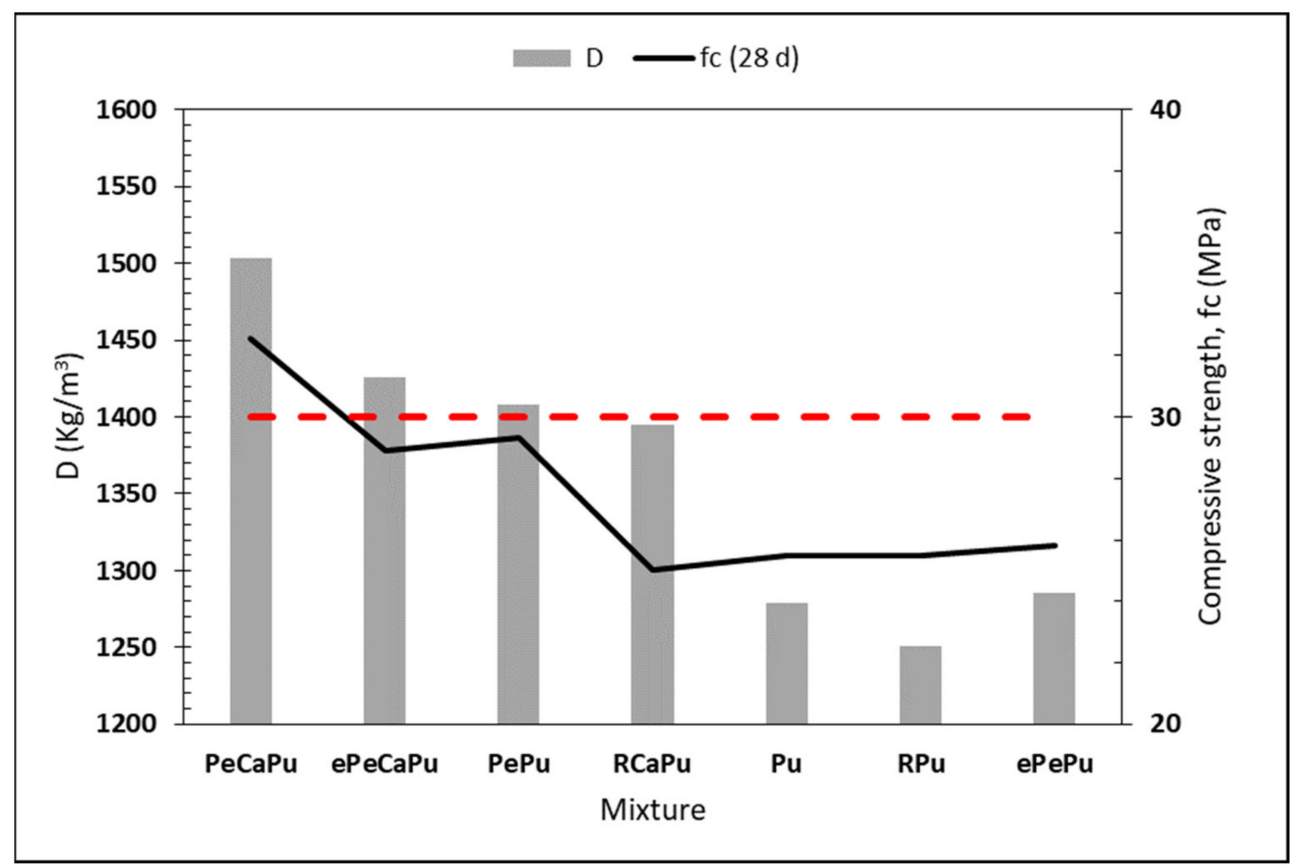

Figure 2. Characteristic compressive strength $\left(\mathrm{f}_{\mathrm{c}}\right)$ at the age of 28 days with respect to the density of LWC mixtures.

The experimental results of all the studied durability parameters-open porosity $(\mathrm{OP})$, sorptivity $(\mathrm{S})$, and chloride penetration coefficient $\left(\mathrm{D}_{\text {nssm }}\right)$ at the age of 28 days-are presented in Table 5. Open porosity values are reported to be high as the open porosity of the LWAs also counts in the testing measurements and ranged from 19.2 to $29.6 \%$, significantly higher compared to REF $(13.5 \%)$. Nonetheless, the reported sorptivity values related to the capillary porosity of the paste are shown to be similar or slightly increased compared to REF in most mixtures, while in two mixtures $(\mathrm{PeCaPu}, \mathrm{ePeCaPu})$, they were reportedly improved. The values range from $0.069 \mathrm{~mm} / \mathrm{min}^{0.5}$ to $0.103 \mathrm{~mm} / \mathrm{min}^{0.5}$. It should be noted that the coefficient of correlation $\left(R^{2}\right)$ values were found to be near 1 for all specimens, satisfying the prescribed high degree of linearity [31]. 
Table 5. Open porosity (OP) \%, sorptivity (S), and chloride penetration coefficient $\left(\mathrm{D}_{\text {nssm }}\right)$ of concrete mixtures at the age of 28 days.

\begin{tabular}{|c|c|c|c|}
\hline Mixture & OP (\%) & $\mathrm{S}\left(\mathrm{mm} / \mathrm{min}^{0.5}\right)$ & $D_{\text {nssm }}\left(\times 10^{-12} \mathrm{~m}^{2} / \mathrm{s}\right)$ \\
\hline REF & 13.5 & 0.096 & 15.5 \\
\hline $\mathrm{PeCaPu}$ & 21.9 & 0.083 & 5.3 \\
\hline $\mathrm{ePeCaPu}$ & 19.2 & 0.069 & 5.6 \\
\hline $\mathrm{PePu}$ & 23.7 & 0.098 & 6.9 \\
\hline $\mathrm{RCaPu}$ & 27.1 & 0.095 & 9.1 \\
\hline $\mathrm{Pu}$ & 29.6 & 0.101 & 4.1 \\
\hline $\mathrm{RPu}$ & 28.4 & 0.103 & 7.0 \\
\hline $\mathrm{ePePu}$ & 24.4 & 0.102 & 5.1 \\
\hline
\end{tabular}

In contrast, it was recorded that the chloride penetration coefficient $\left(D_{n s s m}\right)$ was improved for all the mixtures, exhibiting lower values compared to the REF mixture. The

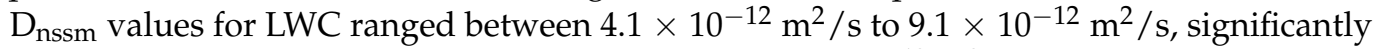
lower compared to conventional (REF) mixture $\left(15.5 \times 10^{-12} \mathrm{~m}^{2} / \mathrm{s}\right)$. According to the classification given by Nilsson et al. [35], all lightweight concrete mixtures were characterized in terms of chloride penetration resistance as "extremely high" and "very high", while "low" in the case of conventional concrete. The Pu mixture was found to have the best performance in terms of chloride penetration resistance.

In order to better demonstrate the effect that LWAs have on durability, Figure 3 illustrates the changes (\%) in the studied durability parameters compared to the REF mixture and with regard to the fines $(<250 \mu \mathrm{m})$ content expressed by cement mass $(\%)$. Unsurprisingly, open porosity is burdened with the porosity of the LWAs which proved to be more influential in the case of $\mathrm{RPu}$, since both aggregates $(\mathrm{R}, \mathrm{Pu})$ have increased porosity values, as it has been also reported in their water absorption values (Table 2). It is also depicted in Figure 3, that the greater the fines content is (\%), then the more OP (\%) values are reported. In contrast, the addition of LWAs in some mixtures favors sorptivity, whereas, for instance, in the $\mathrm{PeCaPu}$ and $\mathrm{ePeCaPu}$ mixtures, sorptivity is decreased. It seems that when $\mathrm{Ca}$ aggregates are combined with $\mathrm{Pe}$ and $\mathrm{Pu}$, as happened in the $\mathrm{PeCaPu}$ or ePeCaPu mixtures, a reduction in sorptivity could be reported. It must be also noted that the fines content of LWA in these mixtures ranges at low values (approximately $50 \%$ of the cement content). Thus, fine grains of Pe and Pu aggregates, when they are ranged in optimized values, could fill the capillary porosity and therefore improve the sorptivity of the paste.

The most explicit results are reported for the chloride penetration coefficient $\left(D_{\text {nssm }}\right)$, where it is well depicted that all the concrete mixtures exhibit improved resistance (Figure 3). The improvement is (approximately) between 40 and $70 \%$ compared to the chloride penetration coefficient of the REF mixture. In general, by increasing the content of fine grains of LWAs and especially of $\mathrm{Pu}$, the $\mathrm{D}_{\text {nssm }}$ values decrease, implying improved resistance to $\mathrm{Cl}^{-}$penetration. The same conclusions regarding the beneficial role of fine grains of pumice were met in the literature [36,37], where it was also reported that its effect was more pronounced by the curing time. Wherever Pu aggregates participated in the LWA blend, the $D_{\text {nssm }}$ values were registered as low despite the increased OP values. It should be considered that although it is well known that porosity favors penetration [38], it seems that the porous system of $\mathrm{Pu}$ does not at all favor the migration of the chlorides, by providing path tortuosity [39]. Reduced $\mathrm{Cl}^{-}$migration can also be attributed to the dense interfacial transition zone (ITZ) between the lightweight aggregates and cement paste $[40,41]$. Therefore, it could be said that when Pu aggregates are used in the LWA blend, any negative influence that the OP may have on the $\mathrm{Cl}^{-}$penetrability is counterbalanced. In the cases of $\mathrm{PeCaPu}$ and $\mathrm{ePeCaPu}$, the low $\mathrm{D}_{\text {nssm }}$ values are consistent with the comparatively lower values of sorptivity, respectively. 


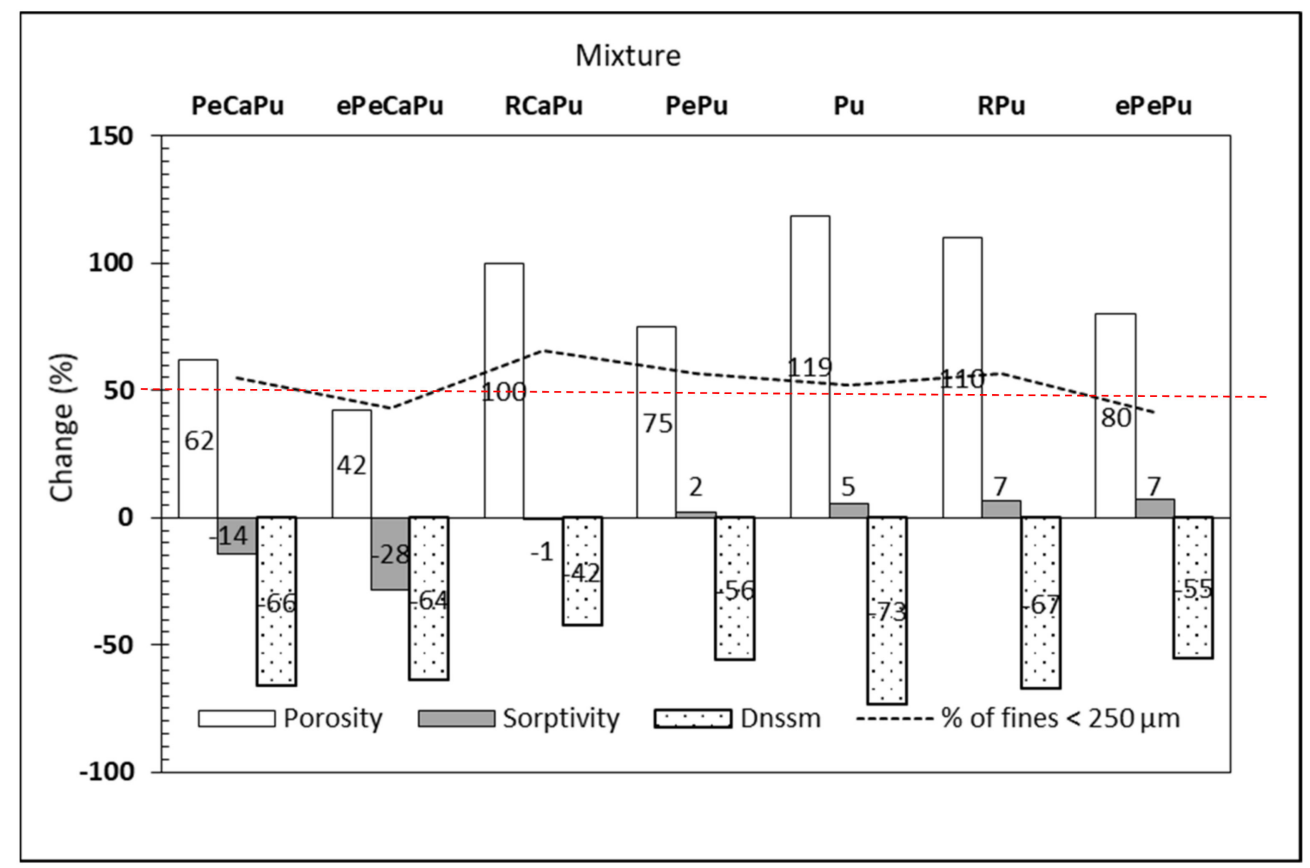

Figure 3. Changes (\%) in OP, $\mathrm{S}$, and $\mathrm{D}_{\mathrm{nssm}}$ of LWC mixtures at the age of 28 days compared to reference mixture (REF) and with respect to the content (\%) of fines $<250 \mu \mathrm{m}$.

Naturally, as the paste structure is expected to be improved over the curing time, durability is also expected to be enhanced. Figure 4 depicts the change (\%) compared to the REF mixture on two durability parameters that were monitored over time-namely the OP and $D_{\text {nssm. }}$. It is shown that OP decreases after 90 days and its change compared to REF is lower, echoing the paste structure improvement that occurs over time which moderates the burdening role of LWAs. Similarly, and to a greater extent, the decrease in $\mathrm{D}_{\text {nssm }}$ compared to the REF mixture is reported to be even more intensive after 90 days, again confirming the effect that curing time has on paste structure and therefore on the chloride resistivity of the LWC. It was also noticed that the time effect was more prominent for $\mathrm{D}_{\text {nssm }}$ than for OP. Moreover, in terms of $\mathrm{D}_{\mathrm{nssm}}$, all LWC mixtures could be considered equivalent, exhibiting a degree of improvement near to $90 \%$ compared to the REF mixture. Impressively, the RPu and $\mathrm{RCaPu}$ showed very high resistance to $\mathrm{Cl}^{-}$and it seems that after the age of 28 days they became capable of equalizing their performance to those of other LWC mixtures. This evidence is a strong fact when supplementary cementitious materials such as rice husk ash are employed in concrete, as it is well known [42]. However, further study on this behavior is needed in order to soundly conclude under which circumstances the use of $R$ as a concrete aggregate could also contribute to its durability.

In Figure 5, the results from the carbonation test are presented. As expected, the porous nature of LWAs does not provide any resistance against carbonation and the carbonation depth is reported to increase in all the LWC mixtures compared to the REF mixture. Similar conclusions were drawn by Samimi et al. [43], who also attributed this effect to the increased porosity of LWA blend, as well as to the reduced values of $\mathrm{Ca}(\mathrm{OH})_{2}$ content as a result of any inherent pozzolanicity that they may provide. As far as the LWA blend is concerned, it seems that the involvement of $\mathrm{Pe}$ or ePe-and naturally, of $\mathrm{Ca}$-in the aggregate blend increases the resistance of $\mathrm{LWC}$. Therefore, the ePeCaPu, ePePu, and $\mathrm{PeCaPu}$ mixtures exhibited the best resistance between LWC mixtures. In contrast, the concrete mixture $\mathrm{Pu}$ that only contained pumice aggregates showed a weak resistance. Finally, both the $\mathrm{RPu}$ and $\mathrm{RCaPu}$ mixtures that contained $\mathrm{R}$ as an aggregate also showed very weak resistance. Obviously, the addition of rice husk ash in the form of aggregate addition does not manage to deliver its well-known beneficial action for the skeleton of concrete and therefore low resistance against carbonation is recorded in these mixtures [42]. However, the pozzolanic reactivity of $\mathrm{R}$ (specimens were tested after 90 days of curing) 
must be also considered, as the lower $\mathrm{pH}$ values of the paste pores solution could lead to an overestimation of the carbonation depth. In any case, when pozzolanic materials are incorporated in concrete, the carbonation depth is affected by both the modified hydration mechanisms and the lower $\mathrm{pH}$ values. Witkowski and Koniorczyk [44] also pointed out the overestimation risk that the phenolphthalein method enhances when pozzolanic additives are employed in concrete.

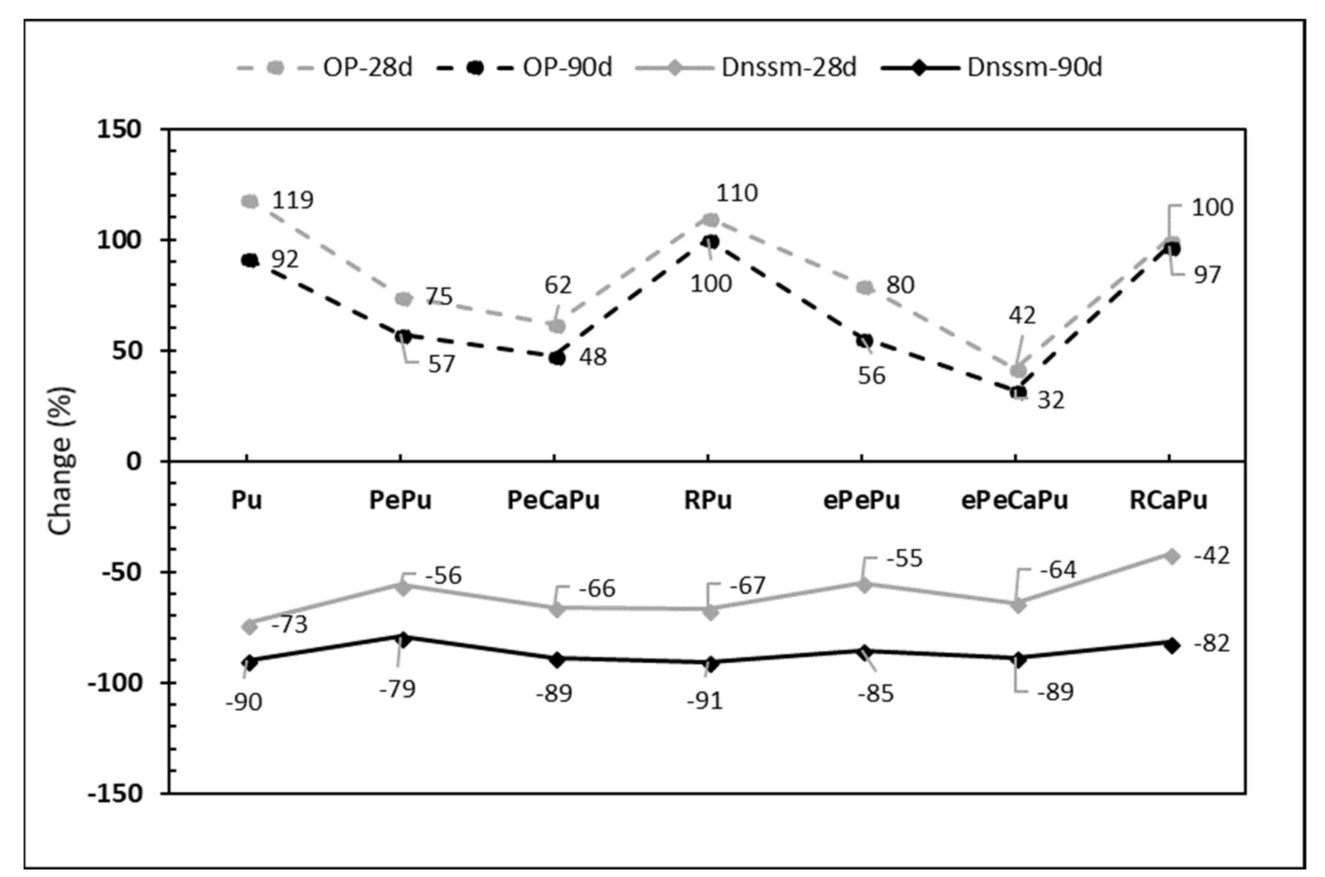

Figure 4. Changes (\%) over curing time (28-90 days) of open porosity (OP) and chloride migration coefficient $\left(\mathrm{D}_{\mathrm{nssm}}\right)$ of $\mathrm{LWC}$, with respect to the REF mixture.

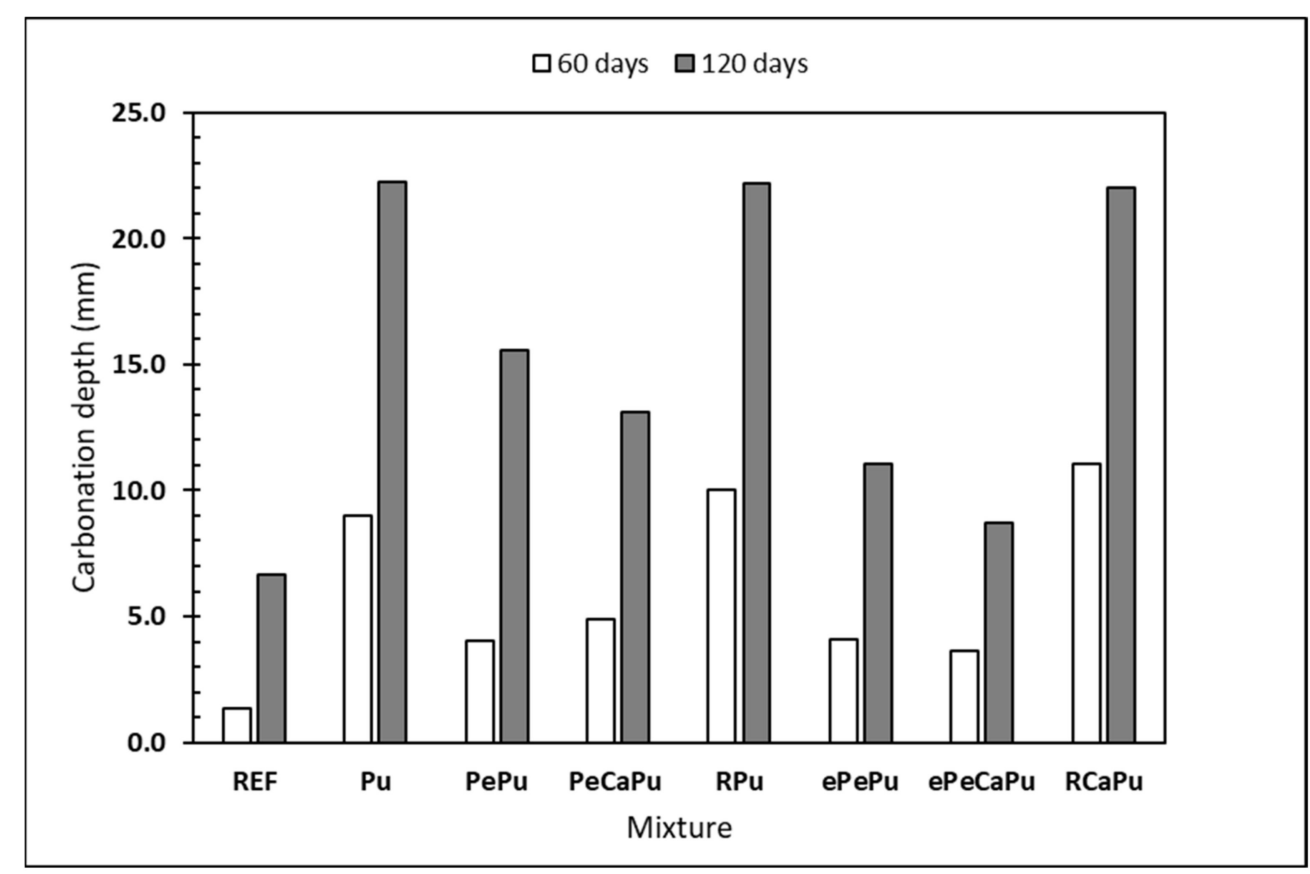

Figure 5. Carbonation depth of LWC mixtures, after 60 and 120 days of exposure. 
In Figures 6-8, the SEM images of the concrete specimens for the $\mathrm{Pu}, \mathrm{PePu}$, and $\mathrm{PeCaPu}$ mixtures are presented, respectively. The images are taken at specific areas that include both $\mathrm{Pu}$ coarse aggregates and their interfacial transitional zone (ITZ) with cement paste. Comparing the mixtures, through the series (a) of the images (Figures 6-8), some cracks were detected in the ITZ of $\mathrm{Pu}$ and $\mathrm{PeCaPu}$ mixtures, although less in the latter. According to Gopalan and Haque [45], the increased shrinkage $(>50 \%)$ of concrete can generate shrinkage cracking. On the other hand, lightweight aggregates favor ITZ densification as due to their pozzolanic reactivity, improved bonding can occur between the cementitious paste and the surface of pumice aggregates [46]. Focusing on the coarse aggregates (series b, c of Figures 6-8), cement paste has filled the surface pores of the lightweight aggregate. In some cases (Figure $7 \mathrm{~b}$ for the PePu mixture), cracking is detected in the paste that filled the pore, implying that the absorbed in the pores of aggregate water gradually came out during hydration, providing internal curing. It is well reported in the literature [47-49] that internal curing prevents the ITZ from further cracking. It is characteristic that no cracking is detected in this sample (PePu) or at its nearby ITZ (Figure 7a), while, as already mentioned, cracks are reported for the samples $\mathrm{Pu}$ and $\mathrm{PeCaPu}$.

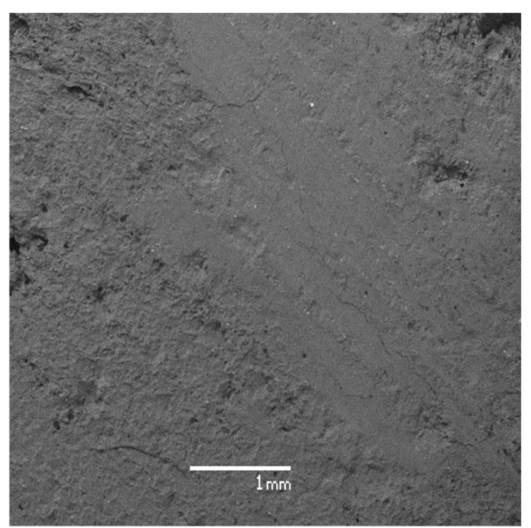

(a)

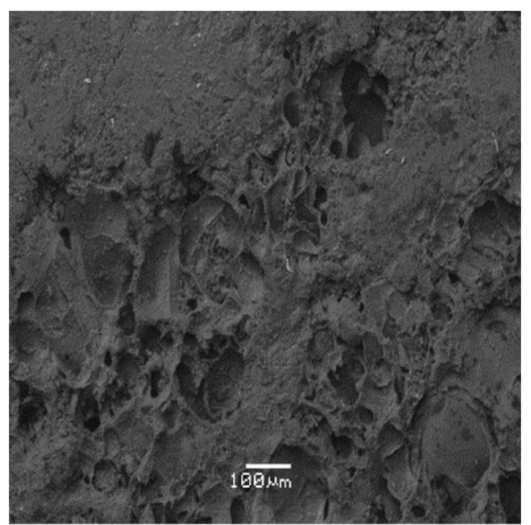

(b)

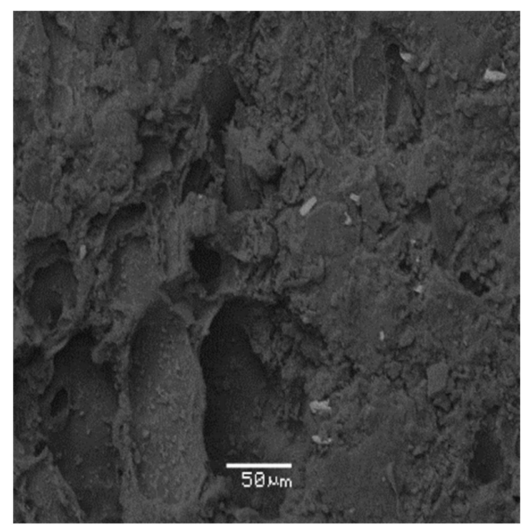

(c)

Figure 6. SEM photos of Pu concrete samples: (a) ITZ area, (b) and (c) aggregate pore filled by cement paste.

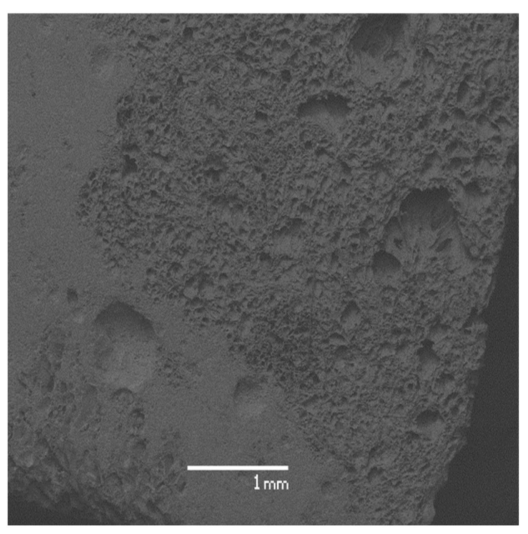

(a)

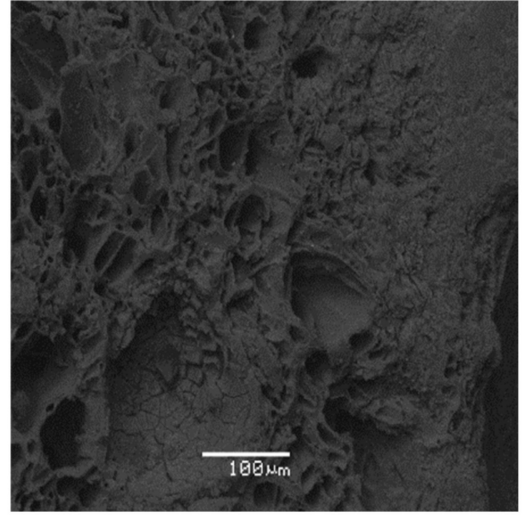

(b)

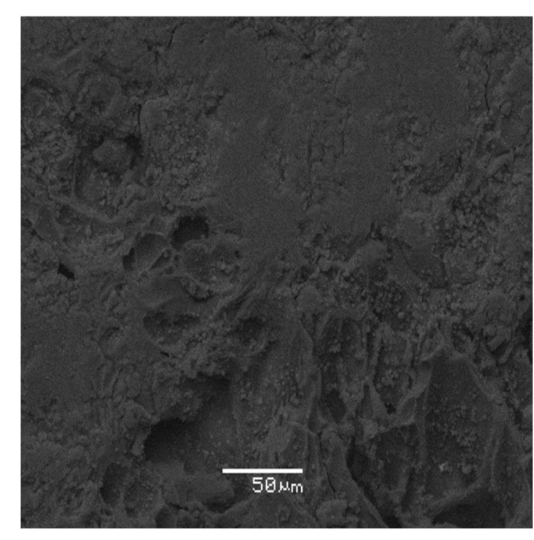

(c)

Figure 7. SEM photos of PePu concrete samples: (a) ITZ area, (b) and (c) aggregate pore filled by cement paste. 


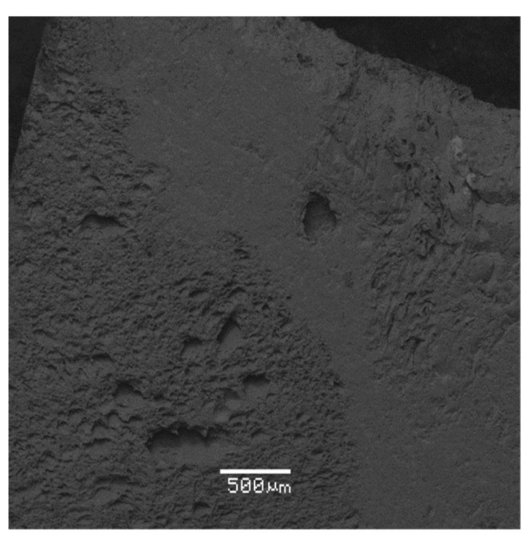

(a)

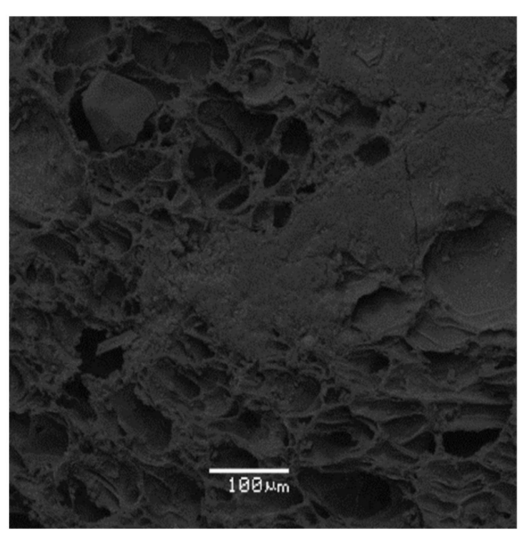

(b)

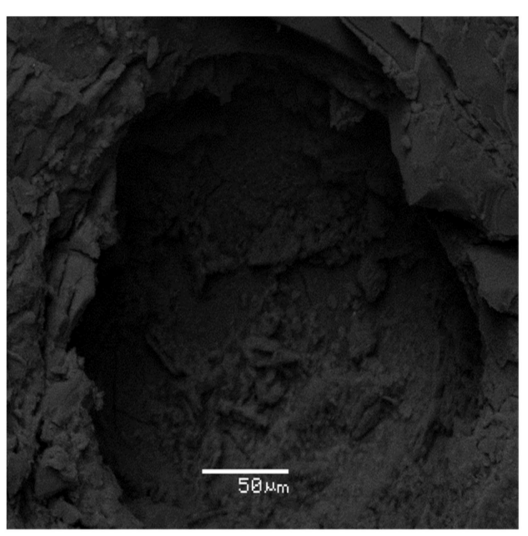

(c)

Figure 8. SEM photos of PeCaPu concrete samples: (a) ITZ area, (b) and (c) aggregate pore filled by cement paste.

\section{Conclusions}

This paper presents the results of strength and durability tests performed on lightweight concrete incorporating pumice, perlite, expanded perlite, and rice husk ash in different percentages. The following conclusions were drawn based on the presented findings:

- Most of the designed LWCs were successfully classified to the designed density category D1.6, while the strength values for 3 of the 6 mixtures were found to be capable of satisfying both the strength (LC28/30) and density (D1.6) categories. The other mixtures, although they were not categorized at the designed strength class, could stand alone as structural LWC mixtures, as they developed satisfactory strength in terms of structural design and use.

- The effect that LWA have on the durability properties is well demonstrated in the case of open porosity, which is burdened with the increasing content of the fine grains of the LWA blend.

- Sorptivity was not particularly influenced and it was found that the combination of $\mathrm{Ca}$ aggregates with $\mathrm{Pe}$ and $\mathrm{Pu}$ promoted its reduction.

- Chloride penetration coefficient $\left(D_{\text {nssm }}\right)$ was found to be intensely vulnerable to the increasing content of fine grains of LWA and it was significantly decreased, especially when the Pu content was high in LWA blend.

- LWC did not register any resistance against carbonation due to the porous nature of LWA. Carbonation depth was reported to increase in all LWC mixtures compared to the REF mixture.

- Both OP and $D_{\text {nssm }}$ demonstrated enhanced values over time. Particularly, $D_{n s s m}$ values decreased further at 90 days and all LWC mixtures exhibited a degree of improvement near to $90 \%$ compared to REF mixture.

- $\quad$ SEM images verified that cement paste filled the pore system of LWA and especially the pores of coarse pumice ( $\mathrm{Pu} \mathrm{0-16).} \mathrm{Water} \mathrm{equilibrium} \mathrm{between} \mathrm{the} \mathrm{saturated}$ pore system of the coarse pumice and the paste of the ITZ seems to have occurred, preventing ITZ from cracking due to drying shrinkage.

- $\quad$ LWC mixtures contained ePe and R did not perform particularly well in terms of both strength and durability compared to other mixtures, to an extent that it could justify their increased processing energy cost.

- Both the strength and durability results of all other LWC mixtures and especially their exhibited high resistance to chlorides' penetration, could revert the aspect that LWC is susceptible to extreme environmental conditions, and enhance its broader application in construction. 
Author Contributions: Conceptualization, E.B., M.S., K.A.; methodology, all authors; validation, E.B., M.S.; formal analysis, all authors; investigation, all authors; resources, K.A., A.C., writing-original draft preparation, M.S.; writing—review and editing, E.B.; visualization, E.B.; supervision, E.B. All authors have read and agreed to the published version of the manuscript.

Funding: This research received no external funding.

Institutional Review Board Statement: Not applicable.

Informed Consent Statement: Not applicable.

Data Availability Statement: The raw data of all the conducted tests, used to support the findings of this study, are available from the corresponding author upon request.

Acknowledgments: The authors gratefully acknowledge TITAN Cement Company S.A., IMERYS Industrial Minerals Greece S.A. Agrino, and NANOVIS Inc., for supplying the materials and T.-M. Zavras for his contribution in part of the experimental work. No endorsement is implied through acknowledgement.

Conflicts of Interest: The authors declare that there is no conflict of interest regarding the publication of this paper.

\section{References}

1. Van Damme, H. Concrete material science: Past, present, and future innovations. Cem. Concr. Res. 2018, 112, 5-24. [CrossRef]

2. Rodrigues, R.; Gaboreau, S.; Gance, J.; Ignatiadis, I.; Betelu, S. Reinforced concrete structures: A review of corrosion mechanisms and advances in electrical methods for corrosion monitoring. Constr. Build. Mater. 2021, 269, 121240. [CrossRef]

3. Poursaee, A. Corrosion of Steel in Concrete Structures, 1st ed.; Woodhead Publishing: Cambridge, UK, 2016 ; ISBN 9781782423812.

4. Naito, C.; Fox, J.; Bocchini, P.; Khazaali, M. Chloride migration characteristics and reliability of reinforced concrete highway structures in Pennsylvania. Constr. Build. Mater. 2020, 231, 117045. [CrossRef]

5. Stanish, K.D.; Hooton, R.D.; Thomas, M.D.A. Testing the Chloride Penetration Resistance of Concrete: A Literature Review. In FHWA Contract DTFH61-97-R-00022 Prediction of Chloride Penetration in Concrete; Department of Civil Engineering, University of Toronto: Toronto, ON, Canada, 1997. Available online: https://rosap.ntl.bts.gov/view/dot/35971 (accessed on 21 July 2021).

6. Tapali, J.G.; Demis, S.; Papadakis, V.G. Sustainable concrete mix design for a target strength and service life. Comput. Concr. 2013, 12, 755-774. [CrossRef]

7. The European Committee for Standardization-CEN. Sustainability of Construction Works-Assessment of Buildings-Part 2: Framework for the Assessment of Environmental Performance; EN 15643-2; The European Committee for Standardization-CEN: Brussels, Belgium, 2012.

8. European Parliament. Official Journal of the European Union. Directive 2010/31/EU of the European Parliament and of the Council of 19 May 2010 on the Energy Performance of Buildings. Available online: https:/ / eur-lex.europa.eu/LexUriServ / LexUriServ.do?uri=OJ:L:2010:153:0013:0035:en:PDF (accessed on 31 July 2021).

9. European Parliament and Council. Official Journal of the European Union. Directive 2008/98/EC of the European Parliament and of the Council of 19 November 2008 on Waste and Repealing Certain Directives. Available online: https: / / eur-lex.europa. $\mathrm{eu} /$ legal-content/EN/TXT/PDF/?uri=CELEX:32008L0098\&from=EN (accessed on 31 July 2021).

10. Collivignarelli, M.C.; Cillari, G.; Ricciardi, P.; Miino, M.C.; Torretta, V.; Rada, E.C.; Abbà, A. The Production of Sustainable Concrete with the Use of Alternative Aggregates: A Review. Sustainability 2020, 12, 7903. [CrossRef]

11. Stratoura, M.; Iaz, D.R.; Badogiannis, E. Chloride Penetration in Lightweight Aggregate Mortars Incorporating Supplementary Cementing Materials. Adv. Civ. Eng. 2018, 2018, 9759167. [CrossRef]

12. Hariyadi; Tamai, H. Enhancing the performance of porous concrete by utilizing the pumice aggregate. Procedia Eng. 2015, 125, 732-738. [CrossRef]

13. Hossain, K.M.A. Volcanic ash and pumice as cement additives: Pozzolanic, alkali-silica reaction and autoclave expansion characteristics. Cem. Concr. Res. 2005, 35, 1141-1144. [CrossRef]

14. Hossain, K.M.A.; Ahmed, S.; Lachemi, M. Lightweight concrete incorporating pumice based blended cement and aggregate: Mechanical and durability characteristics. Constr. Build. Mater. 2011, 25, 1186-1195. [CrossRef]

15. Granata, M.F. Pumice powder as filler of self-compacting concrete. Constr. Build. Mater. 2015, 96, 581-590. [CrossRef]

16. Rashad, A.M. A short manual on natural pumice as a lightweight aggregate. J. Build. Eng. 2019, 25, 100802. [CrossRef]

17. Koukouzas, N.K.; Dunham, A.C.; Scott, P.W. Suitability of Greek perlite for industrial applications, Transaction of the Institutions Mining and Metallurgy: Section B. Appl. Earth Sci. 2000, 109, 105-111. [CrossRef]

18. Rashad, A.M. A synopsis about perlite as building material-A best practice guide for Civil Engineer. Constr. Build. Mater. 2016, 121, 338-353. [CrossRef]

19. Topçu, I.B.; Işikdağ, B. Effect of expanded perlite aggregate on the properties of lightweight concrete. J. Mater. Process. Technol. 2008, 204, 34-38. [CrossRef] 
20. Akyuncu, V.; Sanliturk, F. Investigation of physical and mechanical properties of mortars produced by polymer coated perlite aggregate. J. Build. Eng. 2021, 38, 102182. [CrossRef]

21. Gürsoy, M.; Karaman, M. Hydrophobic coating of expanded perlite particles by plasma polymerization. Chem. Eng. J. 2016, 284, 343-350. [CrossRef]

22. Hebhoub, H.; Aoun, H.; Belachia, M.; Houari, H.; Ghorbel, E. Use of waste marble aggregates in concrete. Constr. Build. Mater. 2011, 25, 1167-1171. [CrossRef]

23. Lynda Amel, C.; Kadri, E.H.; Sebaibi, Y.; Soualhi, H. Dune sand and pumice impact on mechanical and thermal lightweight concrete properties. Constr. Build. Mater. 2017, 133, 209-218. [CrossRef]

24. Dedeloudis, C. S\&B $\mu$-SILICA-An engineered, mineral-based SCM for durable and sustainable concrete. In Proceedings of the 2nd Global CemTrader Conference \& Exhibition 2013-Cement Clinker, Supplementary Cementitious Materials (SCMs), Coal \& Petcoke and Logistics for the Global Cement Cement Industry, London, UK, 23-24 May 2013.

25. Kotwica, Ł.; Pichór, W.; Kapeluszna, E.; Różycka, A. Utilization of waste expanded perlite as new effective supplementary cementitious material. J. Clean. Prod. 2017, 140, 1344-1352. [CrossRef]

26. Stratoura, M.; Zavras, T.-M.; Badogiannis, E.; Sideris, K.; Papadakis, V.G. Development of durable and structural lightweight concrete. In Proceedings of the 2nd International Conference on Sustainable Materials System and Structures (SMSS 2019) Durability, Monitoring and Repair of Structures, Rovinj, Croatia, 18-22 March 2019; pp. 413-420.

27. Antiohos, S.K.; Papadakis, V.G.; Tsimas, S. Rice husk ash (RHA) effectiveness in cement and concrete as a function of reactive silica and fineness. Cem. Concr. Res. 2014, 61-62, 20-27. [CrossRef]

28. Kartini, K. Rice husk ash-pozzolanic material for sustainability. Int. J. Appl. Sci. Technol. 2012, 47, $208-213$.

29. The European Committee for Standardization-CEN. Concrete-Specification. Performance, Production and Conformity; EN-206; The European Committee for Standardization-CEN: Brussels, Belgium, 2014.

30. ASTM International. Standard Method for Density, Absorption, and Voids in Hardened Concrete; ASTM C642-13; ASTM: West Conshohocken, PA, USA, 2013.

31. RILEM TC116-PCD. Determination of the capillary absorption of water of hardened concrete. Mater. Struct. 1999, 32, 178-179.

32. NORDTEST METHOD. Chloride Migration Coefficient from Non-Steady State Migration Experiments; NT Build 492; Nordtest: Slettetoften, Denmark, 1999.

33. ACI Committee 211. Standard Practice for Selecting Proportions for Structural Lightweight Concrete; ACI 211.2-98; Redford Station: Detroit, MI, USA, 1998. [CrossRef]

34. Łaźniewska-Piekarczyk, B. The influence of admixtures type on the air-voids parameters of non-air-entrained and air-entrained high-performance SCC. Constr. Build. Mater. 2013, 109-124. [CrossRef]

35. Nilsson, L.-O.; Ngo, M.H.; Gjørv, O.E. High-performance repair materials for concrete structures in the port of Gothenburg. In Proceedings of the 2th International Conference Concrete under Severe Conditions-Environment and Loading, Tromso, Norway, 21-28 June 1998; pp. 1193-1198.

36. Binici, H. Effect of crushed ceramic and basaltic pumice as fine aggregates on concrete mortars properties. Constr. Build. Mater. 2007, 21, 1191-1197. [CrossRef]

37. Zeyad, A.M.; Tayeh, B.A.; Yusuf, M.O. Strength and transport characteristics of volcanic pumice powder based high strength concrete. Constr. Build. Mater. 2019, 216, 314-324. [CrossRef]

38. Alqahtani, F.K.; Ghataora, G.; Dirar, S.; Khan, M.I.; Zafar, I. Experimental study to investigate the engineering and durability performance of concrete using synthetic aggregates. Constr. Build. Mater. 2018, 173, 350-358. [CrossRef]

39. Anwar Hossain, K.M. Chloride induced corrosion of reinforcement in volcanic ash and pumice based blended concrete. Cem. Concr. Compos. 2005, 27, 381-390. [CrossRef]

40. Zhutovsky, S.; Kovler, K. Effect of internal curing on durability-related properties of high-performance concrete. Cem. Concr. Res. 2012, 42, 20-26. [CrossRef]

41. Elsharief, A.; Cohen, M.D.; Olek, J. Influence of lightweight aggregate on the microstructure and durability of mortar. Cem. Concr. Res. 2005, 35, 1368-1376. [CrossRef]

42. Sahoo, S.; Parhi, P.K.; Chandra Panda, B. Durability properties of concrete with silica fume and rice husk ash. Clean Eng. Technol. 2021, 2, 100067. [CrossRef]

43. Samimi, K.; Kamali-Bernard, S.; Maghsoudi, A.A. Durability of self-compacting concrete containing pumice and zeolite against acid attack, carbonation and marine environment. Constr. Build. Mater. 2018, 165, 247-263. [CrossRef]

44. Witkowski, H.; Koniorczyk, M. The influence of pozzolanic additives on the carbonation rate and Life Cycle Inventory of concrete. Constr. Build. Mater. 2020, 254, 119301. [CrossRef]

45. Gopalan, M.K.; Haque, M.N. Effect of Curing Regime on the Properties of Fly-Ash Concrete. ACI Mater. J. 1987, 84, 14-19. [CrossRef]

46. Madani, H.; Norouzifar, M.N.; Rostami, J. The synergistic effect of pumice and silica fume on the durability and mechanical characteristics of eco-friendly concrete. Constr. Build. Mater. 2018, 174, 356-368. [CrossRef]

47. Zou, D.; Li, K.; Li, W.; Li, H.; Cao, T. Effects of pore structure and water absorption on internal curing efficiency of porous aggregates. Constr. Build. Mater. 2018, 163, 949-959. [CrossRef] 
48. Liu, K.; Yu, R.; Shui, Z.; Li, X.; Ling, X.; He, W.; Yi, S.; Wu, S. Effects of pumice-based porous material on hydration characteristics and persistent shrinkage of Ultra-High-Performance Concrete (UHPC). Materials 2019, 12, 11. [CrossRef]

49. Vázquez-Rodríguez, F.J.; Elizondo-Villareal, N.L.H.; Verástegui, L.H.; Tovar, A.M.A.; López-Perales, J.F.; de León, J.E.C.; GómezRodríguez, C.; Fernández-González, D.; Verdeja, L.F.; García-Quiñonez, L.V.; et al. Effect of mineral aggregates and chemical admixtures as internal curing agents on the mechanical properties and durability of high-performance concrete. Materials 2020, 13, 2090. [CrossRef] [PubMed] 